\title{
Heroic images on runestones in the context of commemoration and communication
}

\section{Introduction}

The general grandness of a runestone and the elaborateness of its carvings reflect on the people who commissioned the monument as well as on the commemorated individual. Particular elements of the carvings, however, provide information about the dead person specifically. The deceased are, for instance, praised for their aptitude on N 68 Dynna: mær hônnurst 'handiest maiden' and Sö 338 Turinge: landmanna bæztr 'best of landholders', or their devoutness on Vg 55 Källby: [k]ristinn mann, saR hafði goða tro til Guðs 'Christian man, who had good belief in God'. ${ }^{1}$ Men were also sometimes honoured by referring to their heroic qualities, both through statements in the inscription and allusions in the decoration. How certain images on runestones could refer to heroism as part of the commemorative message is explored in this paper. First, however, it will be established what defines heroes on runestones and how visual references to heroic qualities may be identified. ${ }^{2}$

\section{Defining heroism}

One can become a hero by performing a deed that requires and attests to extreme courage, surpassing that of others. Characters in myth or legend often do this with the help of a special skill or attribute. Sigurðr Fáfnisbani, for example, killed a monster with an ancestral sword. A heroic deed of a real person can be doing something dangerous, for instance fighting in a battle or partaking in a distant expedition. The Viking Age offered ample opportunity for such hazardous undertakings, which is reflected in how heroes are portrayed in the sources of the day.

In skaldic verse "successful and heroic" warriors are praised mainly by mentioning they did not flee from the battlefield and how they, by being victorious, provided

\footnotetext{
1 The normalizations and English translations of the runic inscriptions discussed in this article are taken from the Samnordisk runtextdatabas.

2 This chapter is based on the paper I gave at the conference in 2010. That study has since then been expanded and is incorporated in my doctoral thesis (Stern 2013), which can be consulted online for a more detailed discussion of this material in a broader context. I am grateful to the editors of this volume for the opportunity to update this contribution accordingly and for their comments on the original manuscript.
} 
food for the beasts of battle. ${ }^{3}$ In the Old Norse poetic tradition, especially in skaldic praise poems, these animals, the wolf, the raven and the eagle, are present on the battlefield to feed off the fallen warriors. ${ }^{4}$ Four memorial inscriptions on runestones express the heroic qualities of the commemorated person in terms of this warrior ideal as well by using the same motif of not-fleeing or by mentioning the feeding of a beast of battle, in these cases the eagle. ${ }^{5}$

Runestone inscriptions contain further, less poetic statements about a deceased person's heroic past. Several monuments state clearly that the men fell in a battle. The verbs that indicate a violent death also seem to refer to warfare, certainly when a location is also given. The more neutral verbs that are used to express the fact that someone died seem to point to a less peaceful death too when the death occurred abroad or on a ship. ${ }^{6}$

Thus the heroic character of a man could be conveyed on a runestone by mentioning what he did or how he died, but also by what he was called in the memorial inscription. On Sö 164 Spånga, the commemorated man is given a "heroic cast" by the statement that he stoð drængila i stafn skipi, 'stood like a drængr in the stern of the ship'. ${ }^{7}$ Drengr was predominantly used for warriors, with the associations of a warband. Another word that was also used in runic inscriptions for a 'partner' in the context of fighting and battles is félagi. Both words could also be used for partners on expeditions that concerned raiding or trading or both. ${ }^{8}$ Heimpegi, which occurs in a few runestone inscriptions, seems to have been applicable for the "closest and highestranking followers of a war-leader or king". 9

In short, mentioning (heroic) achievements of the deceased, which are often also the cause of death, was the most common way of expressing heroism in inscriptions on runestones that commemorated men. Sometimes denominations with martial connotations and a heroic tinge were employed and a few inscriptions refer to the Viking Age warrior ideal by using the poetic motifs of not-fleeing on the battle field and once feeding the beasts of battle.

3 Jesch 2010, p. 166-167.

4 They also occur as such in Eddic heroic and praise poems, while in more mythological Eddic poems, the wolf, raven and eagle appear as mythological animals rather than beasts of battle. These roles can also overlap. See Jesch 2002, comp. also Beck 1970.

5 On DR 295, DR 279, Sö 174 and Sö 179.

6 See Jesch 2001, p. 57-59, 128-129 for an overview and examples.

7 Jesch 2001, p. 120.

8 Jesch 2001, p. 130, 217-225, 229-233.

9 Jesch 2001, p. 235-236. 


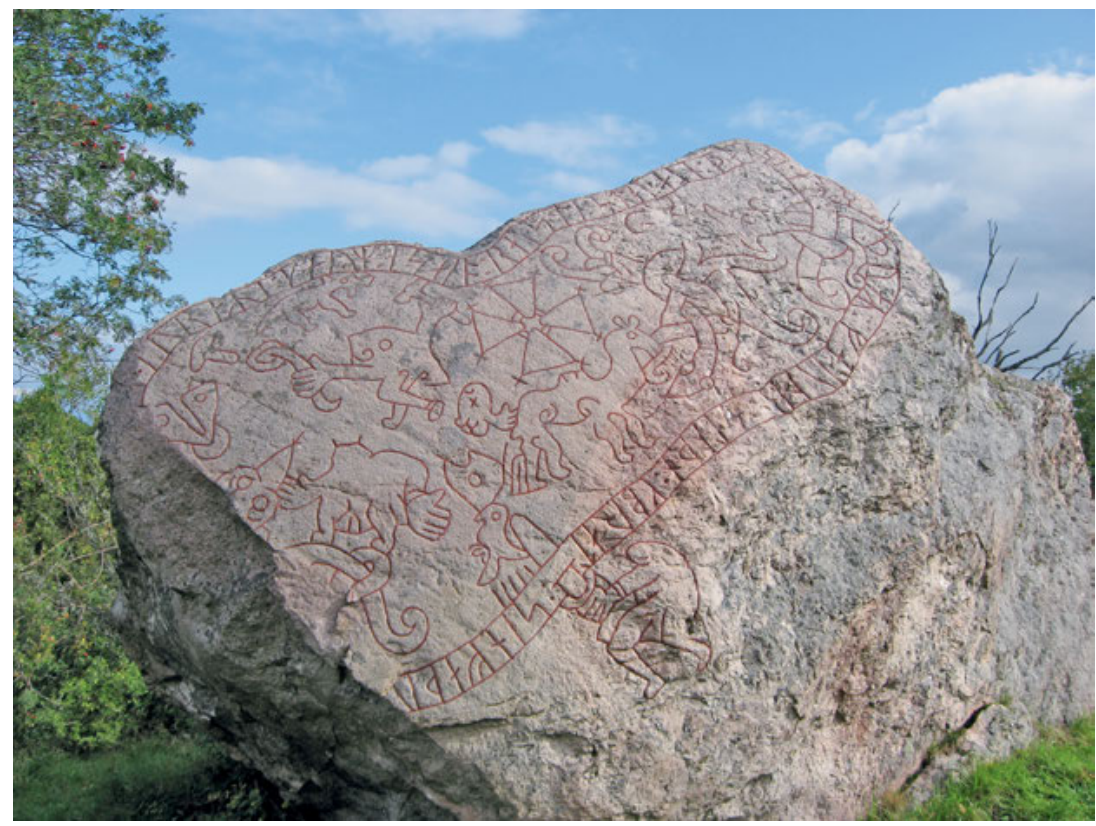

Fig. 1: Sö 327 Göksten (Näsbyholm).

\section{Identifying heroic imagery on runestones}

The references to heroic deeds and characteristics of the commemorated that are discussed above are all textual, but runestones can also contain allusions to heroism in the decoration. Scenes featuring the legendary hero Sigurðr are depicted on some monuments, others contain an image of a warrior figure or a single weapon, and a third group may refer to the late Viking Age heroic warrior ideal through images that might represent a beast of battle. ${ }^{10}$

Sigurðr Fáfnisbani is the only hero from myth or legend that is depicted on Viking Age runestones that can be identified with certainty. ${ }^{11}$ Various events from the stories

10 The images of ships which occur on runestones could be seen as symbols of travel, with heroic connotations of danger and gaining wealth. They are not discussed here, however, since there are too many other interpretations possible, see e.g. Crumlin-Pedersen/Thye 1995. See Stern 2013, p. 34, 36-37 for an overview.

11 The image of the human figure on the chair with snakes wound around its wrists and ankle on Sö 40 has been suggested to be an image of Gunnar in the snake pit, which is also an episode from the Völsung-cycle, e.g. Jansson 1968, p. 117. However, that he is sitting on a chair and various other details of the depiction make this interpretation uncertain, see Oehrl 2006, p. 107-110; Stern 2013, p. 52-53. 
about him are carved on half a dozen Swedish runestones. ${ }^{12}$ He is recognised as stabbing the runic serpent, who doubles as Fáfnir, with his sword on Sö 101 Ramsundsberget, Sö 327 Göksten (Näsbyholm) (fig. 1), U 1163 Drävle, Gs 9 Årsunda, probably on U 1175 Stora Ramsjö, Gs 19 Ockelbo, and possibly on Gs 2 Österfärnebo. He is seen again on Sö 101, sucking his thumb which he burned while roasting Fáfnir's heart. Sigurðr is also depicted (again) on U 1163, Gs 9 and Gs 19, identified by the attribute of the ring Andvaranaut, which he carries to the Valkyrie Brynhildr/Sigrdrifa when she offers him a drink. The two large Sörmlandic monuments further contain images of the horse Grani with the treasure on his back; the birds who Sigurðr can understand after imbibing Fáfnir's blood when he burns his thumb; Sigurðr's foster father Regin with smith's tools, who is decapitated on Sö 101 and who holds Fáfnir's heart on Sö 327; Regin and Fáfnir's brother Otr (or the otter hide); and a decapitated figure who could be either Regin or their father Hreidmarr on Sö 327.

A small group of runestones are decorated with images of armed men who cannot be identified as a particular hero from myth or legend. Four of them are depicted on horseback with a sword and some type of headgear, on Vg 119 Sparlösa, U 678 Skokloster, U 691 Söderby, and U 1161 Altuna (fig. 2). The horseman on DR 96 Ålum 3 does not carry an offensive weapon, but a shield and a triangular object on a stick. This could be a vane, which leads to an interpretation as standard-bearing warrior. ${ }^{13}$

Ög 181 Ledberg (fig. 3 and 4) shows four helmeted figures, clearly warriors too. The upper man on the front of the stone is armed with a sword, a spear and a shield, the lower one only with a shield and a sword, and the two depicted on the back do not carry any weapons. The upper of these two is being bitten in the foot by a wolf-like animal and the lower seems to collapse. (This wolf is discussed further below). U 678 is decorated with one horseman with a sword on the front and another with a spear on the back. Both wear helmets and can be identified as warriors.

The spear-carrying horseman on U 855 Böksta, on the other hand, is clearly part of a hunting scene. The rider is accompanied by two dogs and they chase an antlered animal that is attacked by a small hunting bird. (The larger bird on this monument is discussed below). A smaller figure on skis with a bow and arrow is also depicted on this stone. He either represents the hunting god Ullr or another hunter.

Two men are depicted with a long-shafted axe. They are standing instead of riding on horseback. The man on Sö 190 Ytterenhörna uses his axe as a weapon against the

12 See Stern 2013, p. 45-48 for a more detailed discussion of these images. See Düwel 1986a for a detailed discussion of the literary and visual traditions of this material. See also Liepe 1989 and Margeson 1980. The figures of the master-smith Volundr and Sigurðr Fáfnisbani on Gotlandic picture stones and Manx crosses are not discussed in this paper. Even though they were also carved in a context of commemoration, this paper requires a relatively homogenous body of research material, i.e. the Viking Age runestones from mainland Scandinavia.

13 Jacobsen/Moltke 1941/42, p. 132. 


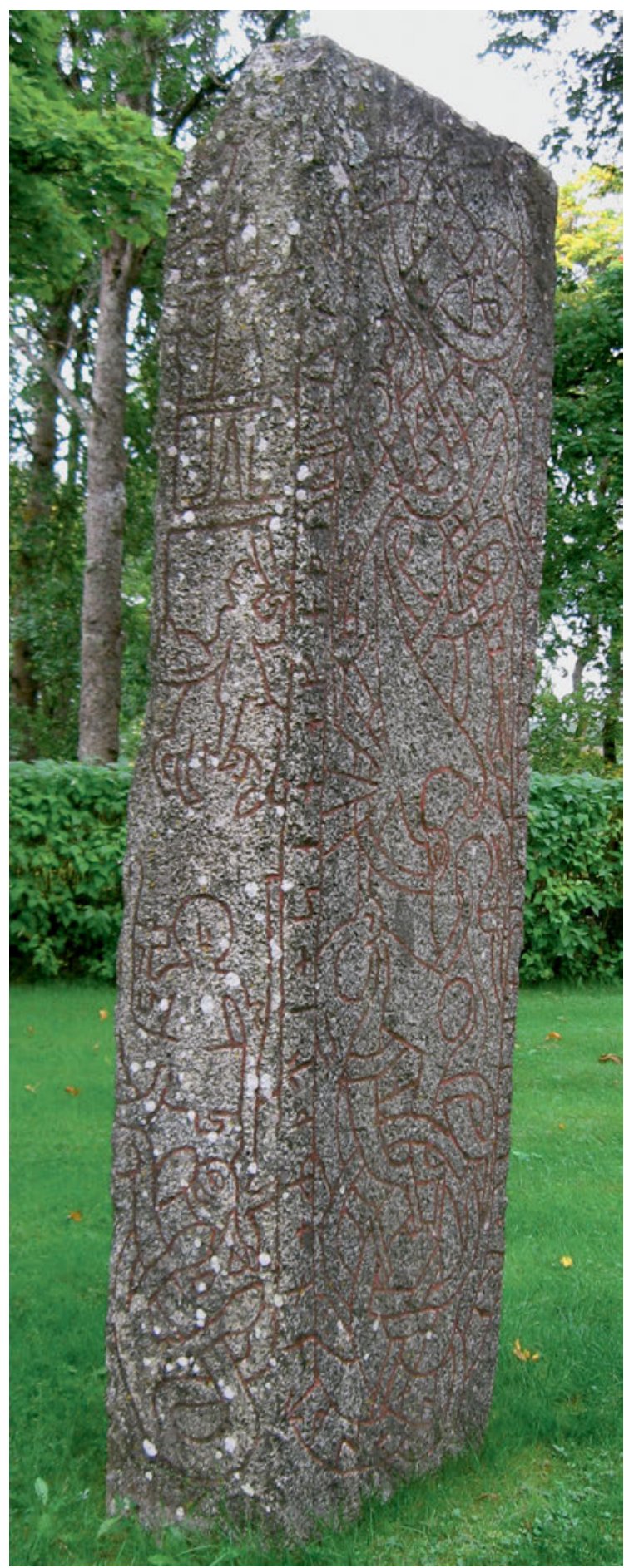

Fig. 2: U 1161 Altuna

(Photo Marjolein Stern). 


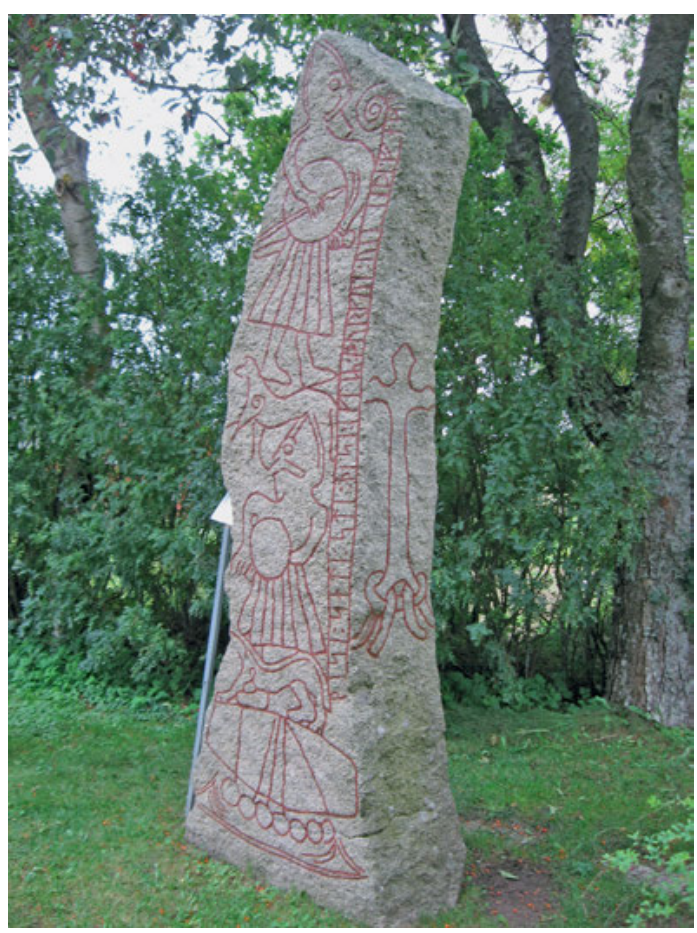

Fig. 3 and 4: Ög 181 Ledberg, back and front (Photos Marjolein Stern).

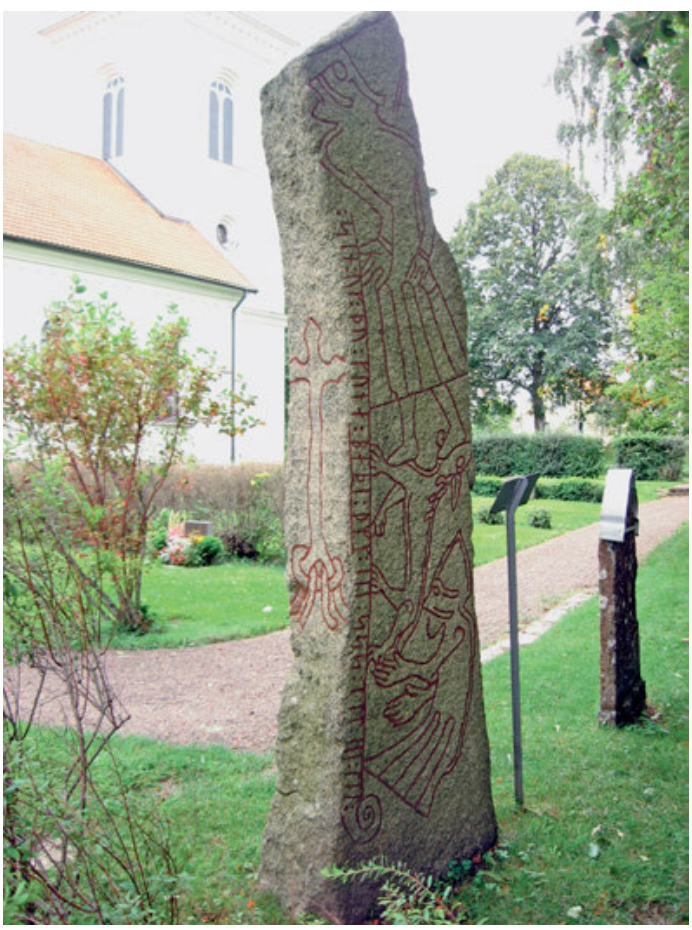


opposing quadruped. On DR 282 Hunnestad 1 the axe is carried over the man's shoulder. ${ }^{14}$

Other interpretations of several of these armed men have been made in a mythological or religious context. ${ }^{15}$ The scene on Sö 190 Ytterenhörna has been interpreted as the god Týr or Óðinn fighting Garmr or Fenrir at Ragnarök. The same scene is reconstructed on two stones of the Hunnestad monument, by considering DR 282 and DR 285 together. The armed rider with a cross on a staff on U 691 is seen as a Christian controller of evil forces, represented by the quadruped with serpentine features that is carved below him. The scene on the back of Ög 181 Ledberg (fig. 4) is often regarded as Óðinn being devoured by Fenrir at Ragnarök, or Viðarr avenging him.

This article, however, considers the runestone material in the wider context of the Viking Age commemoration and praise tradition. The human figures on Sö 190 Ytterenhörna, DR 282 Hunnestad and Ög 181 Ledberg lack attributes or features that identify them as specific mythological characters, unlike for instance Pórr on U 1161 Altuna and the various images of Sigurðr. They can, however, be identified as warriors, by their weapons and headgear. Consequently, they are seen here as heroic figures. In the same light, it is suggested below that some of the animals that can be identified as wolves, ravens and eagles might represent beasts of battle rather than mythological characters. For Ög 181, this interpretation fits the gradual loss of weapons of the warrior-figures on the front and the final collapse of the warrior after he is bitten by the wolf on the back of the stone. It also does not sit uneasily with the cross that is carved on the side of the monument, which a scene of Ragnarök would. The image of the ship on this runestone fits in with either interpretation, whether it is taken literally as vis-

14 Other armed figures are the archers on U 855 and Sö 324, but these images have a mythological or ritualistic rather than a heroic nature. The first holds a bow and arrow and is likely to be an image of the skiing hunting god Ullr (and is either way also part of a hunting scene instead of a warrior). The figure on Sö 324 was possibly depicted with a bow and arrow in one hand and a small hammer in the other, but looks more like a type of ritualistic figure than a warrior, see Stern 2013, p. 241ff.

The images on N 68 Dynna that represent the Nativity and Adoration of the Magi include a figure with an axe over his shoulder in the same position as on DR 282. Unlike the other images on the stone, the outlines of this figure are not carved but only incised shallowly, rather like a sketch. Martin Blindheim 1977, p. 147-150, who discovered the lines, suggests this man represents Joseph as a carpenter in a Nordic version of the Nativity. Not considering an interpretation as a warrior, Blindheim does not mention the parallels on DR 282 and Sö 190.

Attributes that cannot be identified with certainty as a weapon are left out of consideration: the long thin objects held by standing figures on Gs 2 and Gs 19; the tapered object held by the lower horseman on N 61 (fig. 5); and the long object held by the rider on N 66. Horsemen without weapons as on U 375, U 448, U 599, U 1003, U Fv1973;194 and possibly on the damaged Sö 272 and Sö 239 are visually closely related to the warriors on horseback. Since they carry no weapons, however, they cannot be taken as heroic images and they are consequently not discussed here. (Instead, the first three may be depicted with a hunting bird).

15 See e.g. Oehrl 2006, passim for an overview as well as Oehrl 2010, p. 216-221, 227-230 and references there. See also Oehrl's contribution in this volume. 
ual information about the life or death of the commemorated man, or as a symbol in a context of Christianity, Old Norse mythology and/or Viking Age culture in general.

Vg 124 Ryda and U 999 Åkerby are decorated with a single weapon each. On Vg 124, the vertical inscription band is shaped like a sword. The sword in general has strong heroic connotations, also on runestones where it is otherwise depicted as the attribute of either the hero Sigurðr or of other warriors as listed above. The inscription band on U 999 follows the contours of the stone and ends in a spearhead in the centre of the surface. Spears occur in runestone decoration with a martial context on Ög 181 Ledberg (fig. 3 and 4) and U 678 Skokloster, but also in the hunting scene on U 855 Böksta.

In addition to these heroic images of Sigurðr, warriors and weapons, there are several wolves and birds in runestone decoration that may be seen as beasts of battle. These images form more symbolic references to warfare and the late Viking Age heroic warrior ideal. As discussed above, the courage of warriors could be praised by stating they provided food for the wolf, raven or eagle, who in themselves are symbols of battle. This also occurs in at least one inscription on a runestone, Sö 179: Tola let ræisa stæin pennsa at sun sinn Harald, broður Ingvars. PæiR foru drængila fiarri at gulli ok austarla ærni gafu, dou sunnarla a Særklandi. 'Tóla had this stone raised in memory of her son Haraldr, Ingvarr's brother. They travelled valiantly far for gold, and in the east gave (food) to the eagle. (They) died in the south in Serkland.'

Animals in all shapes and sizes are a prominent element in runestone-decoration and they range from the realistic to the fantastic and from highly detailed to very stylized. ${ }^{16}$ The following short survey of the wolf-like (lupine) animals and the birds that look like a raven or eagle illustrates how possible beasts of battle can be identified among them, based on their features and context.

For the purpose of this study, only the images that are more or less realistic depictions of wolves are taken into account. This means that the more fantastic animals with lion-like features, such as long thin tails that point upwards and/or tendrils that form (sometimes antler-like) manes, are not considered to be lupine animals. ${ }^{17}$ The quadrupeds that have features similar to the serpents that carry the inscriptions and

16 See Stern 2013, p. 58-64 for an overview.

17 E.g. DR 42, DR 271, DR 280, DR 285, N 84, Vg 4, Vg 181, Sö 82. Some of these animals are seen as lions, e.g. Jungner/Svärdström 1940-71, p. 7, but also often as wolves, mostly specifically as Fenrir, see e.g. Oehrl 2010, passim, esp. p. 42-44 and 201-202. For example, the beast on DR 271 is regularly interpreted as the wolf Fenrir and the animal on DR 42 Jelling as a lion, while they have very similar features. On the basis that the inscription probably refers to a violent death abroad Anders Andrén 2000, p. 19 suggests that the animal on Sö 82 is a wolf in the sense of a beast of battle. This animal, however, does not have a realistic wolf-like appearance, but head tendrils and an upward pointing tail that interlace. Its legs are also bound.

The animals with possible lupine features on fragments and damaged or lost stones are also not taken into account here since their other features and/or their visual context is unknown: Ög 106, Ög 122, Ög 196, Vg 14. 
other serpent ornamentation are here also not considered to be wolf-like animals either. ${ }^{18}$

Realistic quadrupeds with wolf-like features are carved on several runestones. However, dogs and wolves both belong to the family of canidae and the distinction between them is not easily made. The only biological characteristics on the basis of which the two can be told apart with certainty are a longer snout in wolves and the shape of the tail. This is straight on wolves and always hangs down, while on dogs it can range from sickle shaped to curled and from hanging to pointing upwards. ${ }^{19}$ These differences, especially the shape of the skull, may be difficult to render clearly in stone carving. There are, however, some other characteristics and the visual context of the image can help to distinguish lupine quadrupeds from canines.

Ög 181 Ledberg (fig. 3 and 4) presents a unique opportunity to compare these two kinds of animals on one monument. There are three of them carved on it with different characteristics. The two quadrupeds on the front are depicted horizontally at the feet of the two warriors and are smaller than the one on the back. This larger canine is carved vertically and bites the foot of the warrior above it. It also has "beastly" features like manes and claws, which the smaller ones on the front seem to lack. Also, this beast on the back is further differentiated from the other two by its wide open mouth, long pointed ears and round eye.

The differences in appearance already encourage an interpretation of the two animals on the front as dogs, and the one on the back as a more beastly variety, i.e. a wolf. The positions of the animals also support this. The dogs on the front walk or stand at the feet of their masters, while the wolf on the back bites the warrior above it in the foot. In the context of the gradual loss of weapons and final collapse of the warriorfigures from front to back on this stone, the wolf can be seen as a visual reference to the motif of a beast of battle feeding off the fallen warrior. Although the association between Óðinn and wolves is clear, his connection with Fenrir specifically seems only

\footnotetext{
18 Sigmund Oehrl 2010 employs a different classification of the various quadrupeds that are carved on runestones than I do. He identifies predatory features - mainly claws or fangs - in most of the animals and takes them as representations of the same beast. The animals among these that have bound or crossed legs are identified as the mythological wolf Fenrir, as a symbol of (contained) evil and the end of times. This interpretation is then extended to include also the unbound quadrupeds with a predatory feature regardless of their other features and context. See also Oehrl's contribution in this volume. I, on the other hand, rely more heavily on the features and context for the classification of the quadrupeds. Visual analysis also shows a difference in visual context between the various types I distinguish. It should also be noted that none of the realistic wolves have bound or crossed legs. The possibility remains that the less realistic quadrupeds, especially the bound ones, represent the mythological Fenrir with the complex range of meanings described by Oehrl, while the lupines of a more realistic kind represent the wolf, possibly as a beast of battle. See Stern 2013, p. 58-63, p. 84ff., esp. p. 97-98.
}

19 Miklósi 2007, p. 90-92. 
to have taken shape fully in the $13^{\text {th }}$ century with Snorri's writings. ${ }^{20}$ The kennings in which wolves function as beasts of battle that feed of the warriors, on the other hand, are dated to the $10^{\text {th }}-12^{\text {th }}$ centuries, ${ }^{21}$ which shows this concept was defined earlier and contemporary with these runestones.

The two opposing quadrupeds on DR 314 Lund and the one on the lost DR 286 Hunnestad 5 have the same features and posture as the Ledberg-wolf, so it is safe to say wolves are depicted on those monuments too.22 The wolves on DR 286 Hunnestad and DR 314 Lund look very similar to the one on Ög 181, but they are depicted together with mask-like faces. These motifs also occur separately, so these wolves may also represent beasts of battle as a heroic motif.

Further realistic-looking quadrupeds with wolf-like features like standing ears and a straight tail are carved on Sm 133 Sunneränga, Sö 313 Södertälje (gamla Turingevägen) and U 160 Risbyle. These features are less pronounced, however, and there is no visual context to confirm an interpretation of these images as a wolf. The quadruped on U Fv1978;226 Ösby has a very similar head to the wolves described above, but its tail curves upwards which means it cannot biologically be a wolf. Instead, it may represent a dog and Klaus Düwel has proposed an interpretation as a lion. ${ }^{23}$ These three images have more in common, however, with the depictions of wolves than with those of the smaller dogs or the larger images of lion-like beasts with fantastic features. They also share some characteristics with the dogs on Ög 181 Ledberg and with the small quadrupeds on Sö 101 Ramsundsberget and Sö 327 Göksten (Näsbyholm) (fig. 1) that represent the otter. These two, in turn, have similar eyes, teeth and pointed ears to those of the wolf on Ög 181, but they lack the manes. Maybe such small, relatively realistic looking quadrupeds were to a certain extent generic and multi-employable and within this group of similar looking animals their individual context plays a more important role in their identification than details of their appearance.

A few images of birds on runestones may represent the other two beasts of battle, the raven and the eagle. Identifying the different kinds of birds carved on runestones is a challenging task and again context is an important factor. Some of the birds that are depicted with pronounced beaks and claws, are not part of a hunting scene, a

20 Pluskowski 2006, p. 155.

21 Pluskowski 2006, p. 139.

22 The animal on DR 284 Hunnestad 3 has similar features too. The image fits to large extent Snorri's description of the giantess Hyrrokkin riding on a wolf with a snake as reins (Gylfaginning 49). This interpretation has been regarded with scepticism on archaeological and art-historical grounds, Roesdahl 1991, p. 297-298; Fuglesang 2005, p. 86-87. Either way, this figure does not seem to be a warrior and the wolf not a beast of battle.

Based on a combination of their features and context, small realistic quadrupeds on seven stones can be identified as dogs rather than wolves, like the two dogs on Ög 181. They have a short or cropped tail and they either accompany a horseman or seem to be depicted lying down, slightly curled up, respectively on N 61, U 855, Vg 119 and U 241, U 860, U 904 and U 969.

23 Düwel 1986b, p. 96. 
Sigurðr-scene, sitting on a cross, or fighting another bird, serpent or quadruped with serpentine features. ${ }^{24}$ These images might be visual references to the birds of battle, the eagle and the raven. The most notable visual difference between the two is that the raven has a straight beak and the eagle a hooked one.

A raven is identified by its straight beak on U 920 Broholm, carved a little above the inscription band. This bird is presented as a motif and not as part of for instance a mythological or hunting scene. As such, it could represent one of the beasts of battle. Eagles can be recognized by their hooked beak. Because hunting birds, such as falcons and hawks have hooked beaks as well, the absence of a hunting context is important here too. This is the case for the bird on the side of U 692 Väppeby, which is seen from below with its head in profile. This bird could consequently represent the eagle as bird of battle. The same is true for the images at the top end of the inscription bands on Vg 150 Skattegärden and Vg 103 Håle Ödekyrkogård, which probably represent eagle heads. ${ }^{25}$

Two runestones are decorated with rather elaborate scenes of men on horseback hunting with a bird. The hunting bird sits on the rider's arm on N 61 Alstad (fig. 5) and on U 855 Böksta it is attacking the antlered animal. Both scenes are combined with images of another, larger bird with a hooked beak and claws that is depicted somewhat separate from the hunting scenes. On U 855 this larger bird is carved above the inscription band and on $\mathrm{N} 61$ it is placed above the other images. The latter is also depicted in a different perspective than the other images. It is seen from below like the bird on U 692 Väppeby. These larger predatory birds have a similar appearance and/or position to the raven and eagles described above as possible birds of battle. Another bird fulfils the role of the hunting bird in the hunting scene, therefore the larger birds on $\mathrm{N} 61$ and $\mathrm{U} 855$ can represent an eagle as a bird of battle, adding a heroic motif to the hunting decoration. ${ }^{26}$

Summarizing, the heroic images on runestones consist of depictions of Sigurðr, ${ }^{27}$ of warriors, ${ }^{28}$ the sword on Vg 124 Ryda, and possibly also the spear on U 999 Åkerby. The wolf on Ög 181 Ledberg can be interpreted as a beast of battle. In parallel to this wolf as beast of battle eating a fallen warrior and the "feeding the eagle as beast of

24 For an overview of birds in these contexts see Stern 2013, p. 64-66.

25 The end of the beak on $\mathrm{Vg} 103$ is not visible, but the head is so similar to that on $\mathrm{Vg} 150$ that it most likely also was hooked.

26 A few birds seem to combine aspects of a bird of battle and of a hunting bird. A bird in flight with its claws out is carved behind an animal with a short curled up tail, possibly a dog on U 590 Burvik. It is positioned lower, however, and is not attacking the animal from above as on U 855 Böksta. Instead, it seems to aim for the head of the runic serpent. The bird on U Fv1955;219 Rydbylund is depicted above a quadruped with its claws out, but its straight beak makes an interpretation as a raven possible. The bird on U 1071 Sylta is standing on the inscription band, like the large bird on U 855, but the shape of its beak is not discernible.

27 On Sö 101, Sö 327, U 1163, Gs 9, probably on U 1175, Gs 19 and possibly on Gs 2.

28 On Vg 119, U 678, U 691, U 1161, DR 96, DR 282, Sö 190, and Ög 181. 


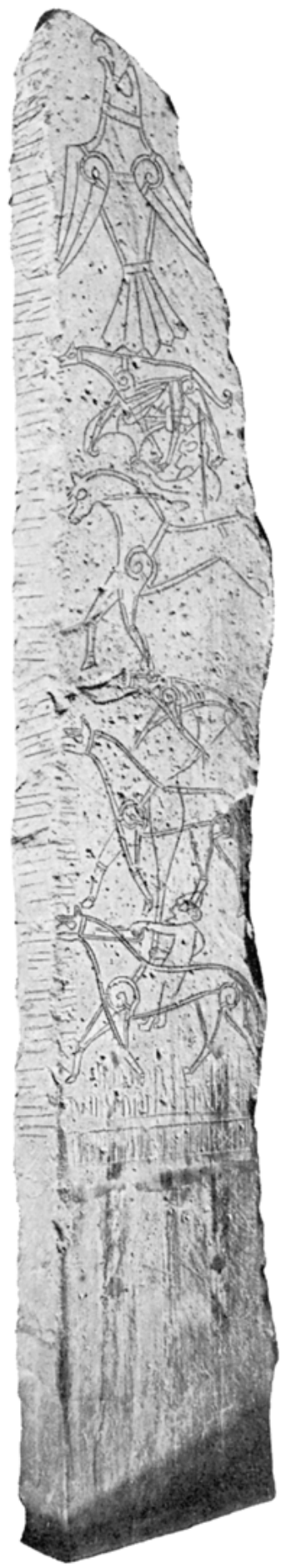

Fig. 5: N 61 Alstad, front (after Olsen 1941, p. 160). 
battle" mentioned in the inscription on Sö 179, the eagles, ${ }^{29}$ raven, ${ }^{30}$ and other wolves $^{31}$ that can be identified on runestones may represent beasts of battle motifs, too. The following section discusses the context of the heroic imagery on the runestones and their commemorative function.

\section{The other carvings on the monuments}

As with all public displays of wealth and status, it is hard to know whether the size and location of a runestone reflects the commissioner's actual social position, or how they wish themselves to be perceived. Regardless of this, the larger the monument is, the more prominent its mark is. There may have been a connection between the use of heroic imagery and the size of memorials in Uppland. The four monuments that are decorated with armed riders are distinctly taller than the three with images of unarmed horsemen..$^{32}$ The majority of runestones decorated with heroic imagery in general are larger than average, with some of exceptional size.

The prominence of images on runestones in relation to the other elements of the design - cross, ornamentation and inscriptions - reflects their importance on the monument. It is usually unknown how the carvings were originally emphasised by colour, which is a complicating factor in studying this. However, the size and position of the images, ornamentation and text also influence their prominence. For instance, an image that is placed above the other carvings is usually more eye-catching than a carving close to the ground, especially from a distance. Whether images are embedded in other ornamentation such as serpents or carved isolated on the surface also influences how noticeable they are. ${ }^{33}$

Crosses decorate half of the Swedish and late-Viking Age Danish runestones. ${ }^{34}$ Also half of the monuments with heroic imagery are decorated with a cross. ${ }^{35}$ Heroic and warrior imagery was given more visual prominence than the crosses they are combined with, both when size and position are taken into account. ${ }^{36}$ The Sigurðr carvings on U 1163 and Gs 9 also dominate over the cross. Those on U 1175 are smaller than the cross, but they are placed in a higher position. This is the other way round for

\footnotetext{
29 On Vg 103, Vg 150 and U 692.

30 On U 920.

31 On Ög 181, DR 286 and DR 314.

32 Between 2-3 metres tall compared to approximately 1.85 metres.

33 See Stern 2013, p. 84-113.

34 Lager 2002, p. 95-96.

35 There is no cross on Vg 119, Vg 124, Vg 150, U 692, U 999, U 1161, Gs 19 and DR 314. DR 282 and DR 286 do not include a cross themselves, but on the other inscribed stone of the Hunnestad monument, DR 283, a cross is carved at the top of the surface framed by the inscription band.
}

36 On DR 282, Ög 181, U 678, U 691. 
those on Sö 327, where the cross is carved in the prominent top position, but the scenes of the Sigurðr stories together occupy a much larger part of the surface. Lupine beasts also tend to visually dominate over the cross. Birds and crosses are usually roughly of equal visual prominence, except for the one on U 920 Broholm, which is decorated with two large crosses. ${ }^{37}$

The inscriptions on the runestones with heroic imagery seldom refer to heroism. Only Vg 119 Sparlösa possibly refers to battle. ${ }^{38}$ The deaths that are mentioned on U 1161 Altuna (arson: baðiR fæðrgaR brunnu 'both father and son(s) were burned (inside)’39) and U 691 Söderby (murder: myrðan) are violent, but not necessarily heroic. The inscriptions give various other kinds of textual information. ${ }^{40}$ Some consist of the memorial formula only, which informs us of the names of the commissioners of the monuments and the commemorated persons and their relationship. ${ }^{41}$ On four of these runestones carvers have identified themselves at the end of the inscriptions ${ }^{42}$ and the inscription on Vg 119 Sparlösa contains the phrase rað runaR paR rægi[n]kundu <iu> par 'interpret the runes of divine origin there'. Several inscriptions refer to the status and social role of the commemorated men through the use of the epithets pegn, ${ }^{43}$ bóndi, ${ }^{44}$ and landmænn 45 and some of these men are called góðr 'good, able'46 and

37 Stern 2013, p. 97.

38 Gaf ... at gialdi 'gave ... as payment', Alrikr ugð[i]t? Aivisl 'Alríkr feared(?) not Eivísl', sigmarr hæti 'is called celebrated-for-victories', and mæginiaru? 'great battle'?

39 Brenna inni indicates death by arson. The reading of inni is uncertain, however, so whether the burning of the men was an accident or happened on purpose is not clear, Wessén/Jansson, 1953-58, p. 613. Brenna or brinna, which only occurs on this stone, is not mentioned among causes of death listed in Jesch 2001. It is included by Thedéen 2009, p. 63, but not explained any further.

40 Except for on U 1175, where the serpent band is filled with symbols that resemble runes, but cannot be read. There is an inscription in readable runes on Sö 327, but only a few words of it can be interpreted. On these and other non-lexical and non-runic inscriptions, see most recently Bianchi 2010, p. 176-178, 191-193.

$41 \mathrm{Vg} 124, \mathrm{U}$ 692, DR 282 and the remains of Gs 9 and Gs 19.

$42 \mathrm{Vg} 119$, Sö 190, U 678 and U 1161. On the latter two this is the only addition to the memorial formula.

43 On Vg 103 and Vg 150. In runestone inscriptions pegn implies a wealthy landowner or magnate, Jesch 2001, p. 226-227; Jesch 2012, p. 41-42.

44 Also on Vg 150 and on U 999 Åkerby (which incidentally commemorates a man called Pegn). In the context of runestone inscriptions bóndi has connotations of landownership in general, but can also refer specifically to a husband. Its various meanings may largely be covered under 'head of household', cf. Sawyer 2000, p. 108-110, Düwel 1975, p. 185-191.

45 On DR 314. The meaning of landmaðr could range from inhabitant of a region to farmer to landowner, but is in this context likely to be closer to the latter, Jesch 2012, p. 39-40; Düwel 1975, p. 195-199; see also An English Dictionary of Runic Inscriptions in the Younger Futhark, "landmaðr". 46 On DR 314, Vg 103, Vg 150 and U 692. Because góðr is also often used to qualify pegn and dreng, it has been suggested the word indicated a specific social role in its own right, see Düwel 1975, p. 187-188 and Sawyer 2000, p. 107-111 for examples of such interpretations. However, its wider applicability, including to women, suggests it may be better to regard it as a general term of approbation, see also An English Dictionary of Runic Inscriptions in the Younger Futhark, "gōðr". 
sniallr 'able, valiant, good'. ${ }^{47}$ In addition, prayers for the soul or spirit of the deceased are included in the inscriptions on four of the monuments with heroic imagery. ${ }^{48}$ Sö 101 Ramsundsberget records the construction of a bridge, which adds to the grandness of the memorial and was considered a good Christian deed..$^{49}$ Hence the addition that the bridge was made for salu 'for the soul of' the commemorated Holmgeirr. Vg 150 Skattegården, in contrast, contains an invocation to Pórr and Ög 181 Ledberg includes the spell pmk:iii:sss:ttt:iii:1[(1)]1, pistill/mistill/kistill, 'thistle, mistletoe, casket'. ${ }^{50}$

On most memorial stones with heroic images and crosses, the Christian message is only communicated visually and not also in the inscription, ${ }^{51}$ but U 920 Broholm is carved with both. This monument contains two crosses as well as a prayer for the soul. Furthermore, on U 691 Söderby, which has a prayer in the inscription, a small cross on a staff is held by the horseman. In Uppland, where these memorials are found, only $12 \%$ of the runestones are carved with a combination of visual and textual markings. ${ }^{52}$ It seems it was especially important that the Christian message on U 920 was understood, since it is communicated through both media. On the monuments with either a verbal or visual Christian reference these are much less prominent, and regularly secondary to the heroic imagery. Apparently, it was sometimes decided to give the visual reference to heroism prominence over the display of the Christian message. This seems to be the case especially when it concerns a warrior image. ${ }^{53}$ Conversely, the crosses that are combined with images of Sigurðr on raised stones and the possible eagles as beasts of battle are prioritised over the images. ${ }^{54}$ Although these heroic references clearly function against a Christian background, the Christian message of the monument is generally secondary to the display of heroism.

\footnotetext{
47 On U 1163 and Gs 2.

48 On Sö 190, U 691, U 920 and DR 96.

49 Gräslund 2002, p. 42.

50 Stern 2013, p. 127.
}

51 None of those that contain neither visual nor textual Christian expressions are in their original location (Vg 119, Vg 124, Vg 150, U 692, U 999, U 1161, Gs 19 and DR 314). Consequently, their spatial relation to for instance a Christian burial ground or church they might have had cannot be taken into account, see Williams 1994. The lack of an explicit Christian message, however, does not necessarily mean the stones were not raised in a Christian context.

52 Stern 2013, p. 164.

53 As on U 678, Ög 181 and the Hunnestad monument.

54 Respectively U 1163, U 1175, Gs 9 and Vg 103 and U 920. 


\section{Visual communication in a commemorative context}

Commemorative skaldic poetry and burial customs are Viking Age commemoration practices that use similar expressions, imagery, and objects to what is represented on runestones. 55 These parallels can help to reconstruct the complex, multi-faceted way in which the heroic images on runestones communicated part of the memorial's message.

In poetry, the motif of 'not fleeing on the battlefield' is applicable to the defeated warrior to indicate he died a heroic death. ${ }^{56}$ 'Feeding the beasts of battle' is also mostly used to praise victorious warriors, but it can be used as well in a way that is "specific, describing the warrior's action in a particular battle, or general, praising the warrior for his prowess in a campaign or in the whole of his career". ${ }^{57}$

The various visual references to heroism on runestones serve a similar range of functions. If the images are taken to communicate information about the deceased person's identity, battle-imagery may have indicated the cause of death of the commemorated man, instead of this being mentioned in the inscription. Despite not being victorious, dying in battle was heroic. Alternatively, heroic images could refer to battles the man fought in during his life in which he was victorious, and not to the cause of death.

The latter possibility is supported by a similar textual construction in two runestone-inscriptions. On Sö 55 Bjudby it is said of Hefnir that he travelled to England, but died at home: VaR til Anglands ungR drængR farinn, varð pa hæima at harmi dauðr. U 1016 Fjuckby was raised in memory of Ljót's two sons, of whom Âki perished abroad and the other died at home. Depending on the reading, the addition Styrði [k]nærri, kvam hann Grikk(hafniR) 'steered a ship, came to Greece (or Greek harbours)' could apply to the first or the second son. ${ }^{58}$ Thus in certainly one and possibly two out of the three inscriptions that mention home as place of death this is compensated by statements about heroic events that are clearly not related to the death of the commemorated men, but to their activities during their life. Presumably, many of the stones on which the manner of death is not specified commemorate someone who died death at home of old age, disease or an accident. ${ }^{59}$ Depictions of warriors, weapons and beasts of battle could function in the same way as the inscription-elements on Sö 55 and U 1016, i.e. to “mention” the deceased's heroic qualities in general or to indicate that he fought successful battles during his life before dying peacefully at home. As discussed above, only two of the inscriptions on stones with heroic imagery specify the manner of death, through arson on U 1161 Altuna and murder on

55 Jesch 2005; Jesch 2010; Stern 2013, ch. 4 for poetry; Stern 2013, ch. 5 for burial customs.

56 Jesch 2010, p. 168.

57 Jesch 2002, p. 254.

58 Wulf 1997; Jesch 2001, p. 100; Thedéen 2009, p. 68.

59 Jesch 2001, p. 57; Thedéen 2009, p. 63. 
U 691 Söderby, which fits in with the tendency that the same information is not expressed in both image and text. 60

The images of warriors may also have had a further, more specific function. A comparison of the armed figures on runestones with weapons that were deposited in burials has shown a tendency to combine swords (and spears) with horses (or riding equipment) on the one hand and have axes be the weapon of a non-equestrian warrior on the other, both in runestone decoration and in early Viking Age burial customs in various Scandinavian regions. ${ }^{61}$ These burials, and so possibly also the corresponding images, represent different kinds of warriors with probably varying social standing. The additional visual and textual information on memorial stones may be regarded as an extension of what was previously contained in the grave. Consequently, the visual representations of warriors on these monuments may have communicated a combined message about the heroic character of the commemorated men and their social identity.

Analogies with skaldic praise poems provide further information about the role of heroic images on memorial stones. In skaldic praise poetry, the heroic warrior ideal is referred to as part of the glorification of the commemorated leader. The specific motifs of not-fleeing and beast of battle through which this was done, seem to have been chosen in order to inspire young warriors and prepare them for the horrors of the battle field. ${ }^{62}$ Since the depictions are less detailed and bloody than the verbal poetic references to the battlefield, the effect on young warriors-to-be would not have been quite the same, but the images might have resonated especially with this subgroup of the runestone's audience.

The audience of runestones is difficult to reconstruct, 63 but it seems the monuments were aimed at an audience wider than the specific target group of (young) warriors that would hear skaldic praise poems. The stones with heroic imagery were all carved in honour of deceased men, but not exclusively so. Gs 9 Årsunda commemorates three or four men and one woman. Furthermore, a woman called Sigríðr commissioned the bridge and caring at Ramsundsberget (Sö 101), Pyrvé raised Vg 150 Skattegården, and Gunna co-commissioned Ög 181 Ledberg. This female involvement shows women had a role in the commemorative practice of runestones and it implicated they were also included audience. The use of various means of communication, textual, visual and material, further suggests an inclusive rather than an exclusive approach to audiences. Specific aspects of the inscription, such as the occasional coded runes, however, could be aimed at a specific in-group. Similarly, the choice of particular heroic imagery could have been aimed at a specific subgroup of the runestone's general audience.

60 See Stern 2013, p. 163-167.

61 Stern 2013, p. 222-229.

62 Jesch 2010, p. 171-172.

63 See e.g. Bianchi 2010, esp. ch. 4 and 5. 
Like the images of beasts of battle, the depictions of Sigurðr also have counterparts in skaldic verse. The runestone images from the stories about Sigurðr refer to three themes. The otter represents the treasure that lies at the root of the dramatic events, since it was to be covered in gold in compensation of Otr's killing by Loki. This treasure is also present as the pack on Grani's back and as the ring Andvaranaut, the last part of the compensation gold, which is carried by the figures on the raised stones and worn on the wrist by Sigurðr and the headless figure on Sö 327 Göksten (Näsbyholm). Sigurðr gains wisdom from the birds after the blood of Fáfnir enables him to understand them and from the Valkyrie when they exchange the toast and the ring. Thus the runestones show Sigurðr performing his heroic deed of killing Fáfnir, the treasure in various forms, and two kinds of scenes in which the hero acquires certain knowledge and wisdom. In some late $10^{\text {th }}$ - and $11^{\text {th }}$-century poems by Icelandic skalds that were composed in praise and commemoration of Norwegian rulers, reference is made to largely the same scenes and the same themes of heroism, wealth and wisdom. ${ }^{64}$ A reference to Sigurðr in verbal and visual expressions of late Viking Age commemoration and glorification was not only a reference to heroism, but also to the acquiring of wisdom and wealth.

\section{Conclusion}

Among other things, this survey has shown that there is hardly any overlap between expressions of heroism in the decoration and in the inscriptions on runestones, despite the number of textual references to heroic deeds or characteristics of the deceased on runestones in general. This is not unique for these memorials. There is for instance also only one runestone that combines a depiction of a ship with mentioning one in the inscription, while many more stones contain either visual or a textual references to ships. ${ }^{65}$ Furthermore, among the memorials with heroic imagery only two contain a verbal as well as a visual Christian reference. It seems the decoration and the inscriptions on these runestones seldom communicate the same explicit message. On a more general level the inscription and the decoration do contribute to the same implicit message of the runestone about the wealth and status of the people involved. This is done through the degree of their elaborateness and exclusiveness.

Roughly half of the runestones with heroic images contain Christian references in the inscription or the decoration. When the latter, the crosses are only rarely more prominent than the heroic message. Although these heroic references clearly function against a Christian background, the Christian message of the monument is generally secondary to the display of heroism.

64 See Stern 2009, p. 902-903 or Stern 2013, p. 196-199 for an overview.

65 Jesch 2001, p. 120. 
The various heroic images each seem to have slightly different functions. The depictions of Sigurðr refer not only to heroism, but also to wealth and wisdom. The details of the heroic warrior-images possibly also indicate social (or even military) standing. Carvings of the beasts of battle refer to the heroic warrior ideal, and may have resonated specifically with young warriors. The verbal and visual elements of the monument are seen, read and interpreted through different processes. They tap into different sets of references and complement each other in the visual communication that was employed on Viking Age runestones.

\section{References}

Andrén, Anders (2000): Re-reading Embodied Texts: an Interpretation of Rune-stones. In: Current Swedish Archaeology, 8, p. 7-33.

An English Dictionary of Runic Inscriptions in the Younger Futhark, University of Nottingham. http://runic-dictionary.nottingham.ac.uk/ (26. 09. 2014).

Beck, Heinrich (1970): Die Tiere der Jagd und Walstatt in den eddischen Liedern. In: Schwab, Ute (ed.). Das Tier in der Dichtung. Heidelberg, p. 55-73.

Bianchi, Marco (2010): Runor som resurs. Vikingatida skriftkultur i Uppland och Södermanland (Runrön 20). Uppsala.

Blindheim, Martin (1977): A Norwegian eleventh-century picture stone: the journey of the Magi to Bethlehem. In: Journal of the British Archaeological Association, 130, p. 145-156.

Crumlin-Pedersen, Ole/Thye, Birgitte Munch (Hrsg.). The Ship as Symbol in Prehistoric and Medieval Scandinavia (Publications from the National Museum. Studies in Archaeology \& History 1). Copenhagen.

Brate, Erik (1911-1918): Östergötlands runinskrifter (Sveriges runinskrifter 2). (Stockholm.

Brate, Erik/Wessén, Elias (1924-1936): Södermanlands runinskrifter (Sveriges runinskrifter 3). Stockholm.

Bugge, Sophus/Olsen, Magnus (1941-1960): Norges Innskrifter med de yngre Runer. Oslo.

Düwel, Klaus (1975): Runische Zeugnisse zu “Bauer”. In: Wenskus, Reinhard/Jankuhn, Herbert/ Grinda, Klaus (eds.). Wort und Begriff "Bauer”: Zusammenfassender Bericht über die Kolloquien der Kommission für die Altertumskunde Mittel- und Nordeuropas (Abhandlungen der Akademie der Wissenschaften in Göttingen, Philologisch-Historische Klasse, Folge 3, Nr. 89). Göttingen, p. 180-206.

Düwel, Klaus (1986a): Zur Ikonographie und Ikonologie der Sigurddarstellungen. In: Roth, Helmut (ed.). Zum Problem der Deutung frühmittelalterlicher Bildinhalte: Akten des 1. Internationalen Kolloquiums in Marburg a. d. Lahn, 15. bis 19. Februar 1983 (Veröffentlichungen des Vorgechichtlichen Seminars der Philipps-Universität Marburg a.d. Lahn, Sonderband 4). Sigmaringen, p. 221-271.

Düwel, Klaus (1986b): Wege und Brücke in Skandinavien nach dem Zeugnis wikingerzeitlichen Runeninschriften. In: Hauck, Karl (ed.). Sprache und Recht. Beiträge zur Kulturgeschichte des Mittelalters. Festschrift für Ruth Schmidt-Wiegand zum 60. Geburtstag. 2 vols. Berlin/New York, p. 88-97.

Faulkes, Anthony (ed.) (2005): Snorri Sturluson. Edda. Prologue and Gylfaginning. Second edition. London. 
Fuglesang, Signe Horn (2005): Runesteinenes ikonografi. In: Øeby Nielsen, Gundhild (ed.). Runesten, magt og mindesmærker. Tværfagligt symposium på Askov Højskole 3.-5. oktober 2002 (Hikuin 32). Højbjerg, p. 75-94.

Gräslund, Anne-Sofie (2002): Ideologi och mentalitet: om religionsskiftet i Skandinavien från en arkeologisk horisont (Opia 29). Uppsala.

Jacobsen, Lis Rubin/Moltke, Erik (1941/42): Danmarks runeindskrifter. 2 vols. Copenhagen.

Jansson, Sven Birger Fredrik (1968): A Newly Discovered Runic Stone from Västerljung, Södermanland. In: Orrick, Allan H. (ed.). Nordica et anglica. Studies in Honor of Stefán Einarsson (Janua linguarum, series maior 22). Den Haag/Paris, p. 115-120.

Jansson, Sven Birger Fredrik (1981): Gästriksland runinskrifter (Sveriges runinskrifter 15). Stockholm. Jesch, Judith (2001): Ships and Men in the Late Viking Age. The Vocabulary of Runic Inscriptions and Skaldic Verse. Woodbridge.

Jesch, Judith (2002): Eagles, Ravens and Wolves: Beasts of Battle, Symbols of Victory and Death. In: Jesch, Judith (ed.). The Scandinavians from the Vendel Period to the Tenth Century, an Ethnographic Perspective. Papers presented at the fifth conference on "Studies in historical archaeoethnology" organized by the center for interdisciplinary research on social stress, which was held in San Marino from 11th to 15th September 1998 (Studies in historical archaeoethnology 5). Woodbridge/San Marino, p. 251-269.

Jesch, Judith (2005): Memorials in Speech and Writing. In: Øeby Nielsen, Gundhild (ed.). Runesten, magt og mindesmærker: Tværfagligt symposium på Askov Højskole 3.-5. Oktober 2002 (Hikuin 32). Højbjerg, p. 95-104.

Jesch, Judith (2010): The Warrior Ideal in the Late Viking Age. In: Sheehan, John/Ó Corráin, Donnchadh (eds.). The Viking Age. Ireland and the West. Papers from the proceedings of the 15th Viking Congress, Cork, 18-27 August 2005. Dublin, p. 165-173.

Jesch, Judith (2012): Runic Inscriptions and the Vocabulary of Land, Lordship, and Social Power in the Late Viking Age. In: Poulsen, Bjørn/Sindbæk, Søren Michael (eds.). Settlement and Lordship in Viking and Early Medieval Scandinavia (The medieval countryside 9). Turnhout, p. 31-44.

Jungner, Hugo/Svärdström, Elisabeth (1940-1971): Västergötlands runinskrifter (Sveriges runinskrifter 5). Stockholm.

Kinander, Ragnar (1935-1961): Smålands runinskrifter (Sveriges runinskrifter 4). Stockholm.

Lager, Linn (2002): Den synliga tron: Runstenskors som spegling av kristnandet i Sverige (Opia 31). Uppsala.

Liepe, Lena (1989): Sigurdssagan i bild. In: Fornvännen, 84, p. 1-11.

Margeson, Sue (1980): The Volsung Legend in Medieval Art. In: Andersen, Flemming G. et al. (eds.). Medieval Iconography and Narrative. A symposium. Procedings of the Fourth International Symposium organized by the Centre for the Study of Vernacular Literature in the Middle Ages, Held at Odense University on 19-20 November, 1979. Odense, p. 183-211.

Miklósi, Ádám (2007): Dog Behaviour, Evolution, and Cognition. Oxford.

Oehrl, Sigmund (2006): Zur Deutung anthropomorpher und theriomorpher Bilddarstellungen auf den spätwikingerzeitlichen Runensteinen Schwedens (Wiener Studien zur Skandinavistik 16). Vienna.

Oehrl, Sigmund (2010): Vierbeinerdarstellungen auf schwedischen Runensteinen: Studien zur nordgermanischen Tier- und Fesselungsikonografie (Ergänzungsbände zum Reallexikon der Germanischen Altertumskunde 72). Berlin/New York.

Pluskowski, Aleksander (2006): Wolves and the Wilderness in the Middle Ages. Woodbridge.

Roesdahl, Else (1991): Nordisk førkristen religion. Om kilder og metoder. In: Steinsland, Gro (eds.). Nordisk Hedendom. Et symposium. Odense, p. 293-301.

Samnordisk runtextdatabas, Department of Scandinavian Languages, Uppsala University. www.nordiska.uu.se/forskn/samnord.htm (26.09. 2014). 
Sawyer, Birgit (2000): The Viking-Age Rune-Stones. Custom and Commemoration in Early Medieval Scandinavia. Oxford.

Stern, Marjolein (2009): Sigurðr Fáfnisbani as a Commemorative Motif. In: Ney, Agneta/Williams, Henrik/Charpentier Ljungqvist, Fredrik (eds.). Preprint papers of The $14^{\text {th }}$ International Saga Conference. Uppsala 9 ${ }^{\text {th-15th }}$ August 2009, 2. Gävle, p. 898-906. www.saga.nordiska.uu.se/ preprint/ (26.09. 2014).

Stern, Marjolein (2013): Runestone Images and Visual Communication in Viking Age Scandinavia. Unpublished doctoral thesis, University of Nottingham. http://etheses.nottingham.ac.uk/4291/ (26. 09. 2014).

Thedéen, Susanne (2009): A desirable, deceitful or disastrous death. Memories of men and masculinities in late Viking age runic inscriptions. In: Regner, Elisabet/von Heijne, Cecilia/Kitzler Åhfeldt, Laila/Kjellström, Anna (eds.). From Ephesos to Dalecarlia, Reflections on Body, Space and Time in Medieval and Early Modern Europe (Stockholm studies in archaeology 48). Stockholm, p. 57-82.

U Fv + number = inscription published in Fornvännen: tidskrift för Svensk antikvarisk forskning. 1906-. Kungl. Vitterhets Historie och Antikvitets Akademien (in collaboration with Svenska fornminnesföreningen, 1942ff.). Stockholm.

Wessén, Elias/Jansson, Sven Birger Fredrik (1940-43, 1943-46, 1949-51, 1953-58): Upplands runinskrifter 1-4 (Sveriges runinskrifter 6-9). Stockholm.

Williams, Henrik (1994): Vad sager runstenarna om Sveriges kristnande? In: Nilsson, Bertil (eds.). Kristnandet i Sverige: gamla källor och nya perspektiv (Projektet Sveriges kristnande, publikationer 5). Uppsala, p. 45-83.

Wulf, Fred (1997): Der Name des zweiten Sohnes in der Fjuckby-Inschrift. In: Blandade Runstudier, 2, p. 185-199. 
Brought to you by | University of Ghent

Authenticated || marjolein.stern@gmail.com author's copy Download Date | 11/30/15 10:29 AM 